\title{
A One Health Perspective to Recognize Fusarium as Important in Clinical Practice
}

\author{
Valeri Sáenz ${ }^{1}$, Carlos Alvarez-Moreno ${ }^{2}$ (D) Patrice Le Pape ${ }^{3}\left(\mathbb{D}\right.$, Silvia Restrepo ${ }^{4}$, \\ Josep Guarro ${ }^{5}$ and Adriana Marcela Celis Ramírez ${ }^{1, *}$ \\ 1 Grupo de Investigación Celular y Molecular de Microorganismos Patógenos (CeMoP), Departamento de \\ Ciencias Biológicas, Universidad de Los Andes, Bogotá 111711, Colombia; v.saenzm@uniandes.edu.co \\ 2 Departamento de Medicina interna Universidad Nacional de Colombia, Clínica Universitaria Colombia, \\ Colsanitas, Bogotá 111321, Colombia; caalvarezmo@unal.edu.co \\ 3 Département de Parasitologie et Mycologie Médicale, EA1155, IICiMed, Université de Nantes, \\ F-44000 Nantes, France; Patrice.Le-Pape@univ-nantes.fr \\ 4 Laboratorio de Micología y Fitopatología (LAMFU), Facultad de Ingeniería, Universidad de Los Andes, \\ Bogotá 11711, Colombia; srestrep@uniandes.edu.co \\ 5 Facultat de Medicina I Ciéncies de la Salut, Departament de Ciéncies Médiques Básiques, \\ Unitat Microbiología, Universitat de Rovira I Virgili, 43002 Reus, Spain; josep.guarro@urv.cat \\ * Correspondence: acelis@uniandes.edu.co; Tel.: +57-1339-4949 (ext. 3757)
}

Received: 7 September 2020; Accepted: 8 October 2020; Published: 20 October 2020

check for updates

\begin{abstract}
Any strategy that proposes solutions to health-related problems recognizes that people, animals, and the environment are interconnected. Fusarium is an example of this interaction because it is capable of infecting plants, animals, and humans. This review provides information on various aspects of these relations and proposes how to approach fusariosis with a One Health methodology (a multidisciplinary, and multisectoral approach that can address urgent, ongoing, or potential health threats to humans, animals, and the environment). Here, we give a framework to understand infection pathogenesis, through the epidemiological triad, and explain how the broad utilization of fungicides in agriculture may play a role in the treatment of human fusariosis. We assess how plumbing systems and hospital environments might play a role as a reservoir for animal and human infections. We explain the role of antifungal resistance mechanisms in both humans and agriculture. Our review emphasizes the importance of developing interdisciplinary research studies where aquatic animals, plants, and human disease interactions can be explored through coordination and collaborative actions.
\end{abstract}

Keywords: Fusarium; One Health

\section{Introduction}

One Health is a concept defined as a worldwide strategy for expanding interdisciplinary collaborations and communications in all aspects of health care for humans, animals, and the environment [1]. Fusarium has been described as a pathogen of humans, animals, and plants, a phenomenon known as trans-kingdom pathogenicity [2,3]. In recent years, human infections by Fusarium have been rising worldwide, mostly involving immunocompromised hosts [3,4]. To understand these human infections, the dynamics among hosts (human/animal), pathogens, and the environment must be explored.

In humans, these fungi cause a broad spectrum of infections, including both superficial (onychomycosis and keratitis) and disseminated diseases (particularly in hematological cancer and neutropenic patients) [5]. Fungal keratitis is not only a common cause of corneal infection in developing countries, but also a significant cause of ocular morbidity and blindness [6,7]. The goal of this article 
is to assess the current conceptions in the One Health approach, to provide information about the host-pathogen interaction, as well to guide clinicians to consider Fusarium as an important human pathogen.

\section{The Fusarium Genus}

The taxonomy of the genus Fusarium, initially described by Link in 1809 as presenting banana shape conidia, has been changing in taxonomy over the years and it has become a controversial issue [8]. Currently, the genus Fusarium has been classified into species complexes, i.e., F. solani species complex (FSSC), F. oxysporum species complex (FOSC), Gibberella (Fusarium) fujikuroi species complex (GFSC), F. incarnatum-F. equiseti species complex (FIESC), F. sambucinum species complex (FSAMSC), F. tricinctum species complex (FTSC), F. chlamydosporum species complex (FCSC), and F. dimerum species complex (FDSC) [9-11]. In addition, the members of FSDC have been included in the genus Bisifusarium [12], and recently, it has been proposed that members of the F. solani species complex be moved to the genus Neocosmospora based on the results of phylogenetic analysis [13]. This includes the species N. petroliphila (F. petroliphilum), N. keratoplastica (F. keratoplasticum), N. falciformis (F. falciforme), and N. solani (F. solani), along with the new species N. gamsii (haplotype 7), N. suttoniana (haplotype 20), and N. catenata (haplotype 43) [14]. However, a recent phylogenomic analysis supports FSSC as Fusarium [15] and the genus name Fusarium for human pathogens in the FSSC [16]. Taking into account that the continuous change of names of these fungi can create some confusion, it has been suggested to refer to these taxa as Fusarium-like [17].

\section{Fusarium in Agriculture}

Fusarium species are broadly distributed in soil, as well as in underground and aerial plant parts, plant debris, and natural substrates [8]. Furthermore, it is found in the air and in aquatic environment, including natural sea water $[18,19]$. For instance, FSSC is a varied group of fungi capable of causing diseases on a wide variety of plants. It is considered the fifth plant pathogen in the list of "top ten fungal plant pathogens" [20]. On the other hand, Fusarium can wither ornamental plants at all production stages. In particular, Fusarium oxysporum f. sp. dianthi and its sister species, F. redolens f. sp. dianthi, can cause severe disease to carnations fields [21]. These pathogens additionally attack cereals that are important to human and animal nutrition (animal food that is found to contain mycotoxin levels above these standards would be rejected in the domestic or export marketplace) [22]. It explicitly infects certain parts of the plants, for example, grains, seedlings, heads, roots, or stems, causing various diseases, reducing product quality, and diminishing crop yields. Some species produce important mycotoxins, such as fumonisin, deoxynivalenol, and zearalenone [22].

Therefore, managing Fusarium outbreaks is a critical issue in agriculture. Efforts made to decrease agricultural losses by the fungal disease incorporates chemical, biological control, and fungicide use, particularly azoles compounds [23,24]. The present use rate for some triazoles, which are the biggest class of azole fungicide, is around $100 \mathrm{~g} / \mathrm{ha}$ of culture [24]. The substantial use of azoles in agriculture is currently a major concern in clinical practice since it could induce antifungal resistance among diverse human fungal pathogens. Indeed, previous studies have demonstrated the presence of environmental resistance to azoles of medical importance in Aspergillus fumigatus isolated from flower fields related to the use of azole fungicides [25-28]. This resistance has also been reported in other environmental sources such as compost sites, public/private gardens, vineyard, and agriculture soil [29,30]. In India, a study that included isolates from patients with keratitis (agricultural workers) and environmental sources including soil, plants, gardens, parks, and agricultural fields reported that $F$. falciforme and F. keratoplasticum were found with high minimum inhibitory concentration (MIC) values to fluconazole, ketoconazole, and terbinafine in both clinical and environmental isolates [31]. Colombia could remain a country of concern, considering its second place worldwide as a flower exporter, including carnations, which is commonly affected by some species of Fusarium. About 6800 hectares are destined for the cultivation of flowers for export, from which 75\% are located in the savannah of Bogotá [32]. Based on 
the Colombian Agricultural Institute report, fungicides acting by inhibition of ergosterol synthesis are approved to be used in the flower industry $[25,33]$. This data foregrounds the necessity to study Fusarium in crops, flower fields, and clinical settings.

\section{Fusarium in Hospital Environment}

Water distribution systems (drains, faucet aerators, shower heads) in hospitals have been identified as potential reservoirs for species of Fusarium. These distribution systems are thought to be responsible for nosocomial infections [34]. Most of the pathogenic species of these fungi have been found in environmental samples, including plumbing systems of hospitals [35]. During hospital outbreaks where immunosuppressed hosts are affected, using a genotyping approach has shown a relationship between hospital water and patient isolates. This suggest that shower is most likely to be the mechanism of aerial dispersal of the conidia in air: it could be responsible for the transmission to the host $[34,36]$. Furthermore, airborne conidia may also represent a relevant source of infection as occurred in the case of poorly sealed chase openings permitting inadequate air exchange and exhausts [37]. A recent study evidenced a genetic relationship between Fusarium species isolated from indoor hospital air with the ones recovered from blood cultures of hematologic patients, which suggest that the air may be a potential source for fusariosis [4]. Airborne fusariosis is considered to be acquired by the inhalation of airborne conidia, as indicated by the occurrence of sinusitis and/or pneumonia in the absence of dissemination [38].

\section{Fusarium and Animal Disease}

Fusarium species represents a common cause of opportunistic infections in aquatic animals, such as seahorses, turtles, dolphins, pinnipeds, and colonization of eggs. Fusarium infection is considered as the primary driver of declining turtle populations around the world [39]. The sea turtle egg fusariosis (STEF) is an emerging disease and is responsible for egg mortality in sea turtles around the world, where most of the cases are related to F. keratoplasticum and F. falciforme [40-45]. During the embryonic development, the eggs spend an extensive amount of time buried under the sand in a sticky and warm consistent temperature, and it has been suggested that these conditions support the development of soil-borne fungi such as Fusarium [41,45]. Clinical manifestations suggest that STEF possibly include the presence of atypically colored areas (e.g., yellow, blue, gray, red) on the eggshell, with more severe infections showing gray hyphal mats on the outside and the inside of the eggs, as well as in the embryos [45]. The clinical signs of infection caused by Fusarium in aquatic animals shift from a superficial invasion of the skin to pulmonary or systemic infections affecting the lungs, the liver, the heart, and the cartilages [39]. Moreover, an infection caused by F. oxysporum in captive-reared fingerlings of golden mahseer has been recently informed in India [46].

Some of the principal hypotheses on the STEF etiology and epidemiology lie in the relationship between beach environments and human environmental sources. F. keratoplasticum and F. falciforme are probably microbiota of beach sand, and there is a relationship between human construction plumbing systems and STEF disease. These pathogens are brought into the sand beach by overflow from plumbing human wastes [41].

Other cases related to animal pathologies are equine keratitis infections [47], in addition to invasive sinusitis and facial mycetoma in dogs [48]. Diversely, raised concentrations of fumonisins in animal feed have been accounted to cause sicknesses, such as Equine Leukoencephalomalacia (ELEM) in horses, and porcine pulmonary edema (PPE) or liver injury in pigs [22]. Trichothecenes mycotoxines produced by Fusarium develop an important role in animal health due to their potential to be topically absorbed, and their metabolites affect the gastrointestinal tract, skin, kidney, liver, and immune system [49]. 


\section{Fusarium in Human Diseases}

In severely immunocompromised patients, fusariosis is the second most common mold infection in humans, right after aspergilosis [9]. These fungi cause superficial (such as onychomycosis and keratitis), locally invasive, and disseminated disease.

\subsection{Onychomycosis}

Onychomycosis is one of the most widely recognized finger and toenail infections with an overall prevalence of 5.5\% [50]. This pathology can affect the physical, functional, psychosocial, and emotional state of the patient [51]. Even though it is not a life-threatening condition, numerous significant anatomical functions of the nail may be affected, with difficulty in walking, embarrassment, and work-related challenges being the most commonly reported issues [51]. Recognized risk factors for onychomycosis are trauma, ageing, obesity, diabetes, participation in fitness activities, immunosuppression (HIV(human immunodeficiency virus), drug-induced), malignancies, sedentarism, and occlusive footwear [50-52]. People who have pedicure treatment are less likely to acquire onychomycosis [53].

Dermatophytes, mainly Trichophyton rubrum, are responsible for most fungal nail infections and about $30 \%$ to $40 \%$ of onychomycosis cases are caused by nondermatophyte molds (NDMs) and yeasts [50]. In South America, studies suggest that Fusarium may be the most common NDM [53,54]. Species identification has a crucial role in this disease, for example, F. keratoplasticum and F. falciforme are the most frequent species isolated in Colombia, and some of these isolates exhibited lower azole in vitro activity [53].

Fungal production of proteases that degrade keratin may facilitate invasion [53]. In addition, histological studies have revealed the capacity of F. oxysporum to invade human nails, including the firm attachment to the nail plate and the dissemination to deep layers, causing disorganization of nail structure [55]. Also, the formation of fungal biofilms is a contributor to persistent infection, which offers advantages such as antifungal resistance, protection against host defenses, increased virulence, communication, metabolism cooperation, and differential gene expression [56-58]. By viewing an infected nail through a scanning electron microscope (SEM) it can be seen that this fungus is able to form a biofilm, by penetrating unassisted nail layers to cause onychomycosis. It can also be seen that the ventral surface of the human nail is more vulnerable to infection than the dorsal surface [56].

\subsection{Keratitis}

Corneal disease is one of the leading causes of blindness worldwide. In 2001, trauma and corneal ulceration were reported as principal causes of unilateral blindness and the global estimate varies from 1.5 to 2 million cases per year [6]. Current epidemiological information proposes that microbial keratitis might be epidemic in South, South-East, and East Asia, and may exceed 2 million cases per year worldwide [59]. Furthermore, it has been demonstrated that fungal keratitis contrasted to bacterial keratitis can be progressively destructive. On the one hand, a retrospective analysis not only found that fungal keratitis was more likely to perforate the cornea than bacterial keratitis $(\mathrm{OR}(\mathrm{Odds}$ ratio $)=5.86,95 \% \mathrm{CI}$ (confidence interval), 1.35-20.66), but also that it leads to an irreversible change [60]. Likewise, around $15-27 \%$ of patients with fungal keratitis require surgical intervention, such as corneal transplantation, removal of ocular contents, and enucleation, as a result of a failed pharmacological treatment [61].

The requirement for prolonged and intensive treatment, resulting in negative ocular outcomes (loss of vision and/or loss of the eyeball), indicate that both the economic and medical implications are substantial [62]. In addition, a correlation between gross national income (GNI) and the etiology of microbial keratitis has been shown. Fungal keratitis is associated with countries with low GNI [63]. Moreover, there are numerous cases of fungal keratitis related to the utilization of contact lenses. Between 2004 and 2006, an outbreak of Fusarium fungal keratitis occurred in contact lens users 
worldwide, owing to a decrease in the disinfection capacity of contact lens solutions [64]. Clinical signs of fungal keratitis include a sudden onset of pain along with photophobia, discharge with a reduced vision, and opacity on the surface of the cornea [65].

The common fungal causative agents are Fusarium spp., Aspergillus flavus and A. fumigatus, and Candida albicans (which is less common in tropical climates) [66]. Fusarium keratitis has increased over the last forty years and it is estimated that around half of all the cases of microbial keratitis in tropical countries are caused by this genus, probably on account of an increasing use of topical steroids and antibacterial agents, as well as a rise in surgical procedures, contact lens use, ocular trauma, chronic ocular surface diseases, and immunocompromised patients [67]. In Tunisia, fungal keratitis represents $83 \%$ of the cases, with $F$. solani being the most prevalent species (66\%) [68]. In Brazil, $25 \%$ of fungal keratitis is caused by Fusarium [69], and in Mexico, F. solani was found in $37 \%$ of the patients [70]. Recent studies conducted in south India have shown that F. keratoplasticum and F. falciforme were the most prevalent species isolated from keratomycoses and environmental settings; in fact, agricultural workers in India often become infected after a corneal injury caused by plant or soil material [31].

The interaction of pathogenic fungi with host cells is the main factor in the pathogenesis of mycotic keratitis. The human central corneal temperature $\left(32.6 \pm 0.70{ }^{\circ} \mathrm{C}\right)$ is suitable for the development of Fusarium [71]. Adherence of microorganisms to host cells through an assortment of adhesins is essential for the initiation of the infection [65]. Consequently, Fusarium keratitis can invade the cornea and the anterior chamber of the eye. Here, in the pupillary area, it forms a lens-iris-fungal mass which affects the normal drainage of the aqueous humor and causes an increase in the intraocular pressure, leading to fungal malignant glaucoma [65,72]. Also, Fusarium mycotoxins can suppress immunity and break down tissues. Certain cytosolic proteins and peptide toxins can destroy corneal epithelial cells [73]. Proteases play an important role in fungal keratitis because they can cause corneal ulcers [65,74]. As described in onychomycosis, the formation of biofilm is another factor that contributes to the pathogenesis of keratitis as well as to antifungal resistance [75,76]. Biofilm proteomics studies in F. falciforme have identified several proteins whose levels changed during the biofilm formation phases, as well as the enzymes involved in the glycolysis/gluconeogenesis and pentose pathways. Some of the proteins involved could promote angiogenesis, adhesion/invasion, and immunomodulation [76].

\subsection{Invasive Disease}

Invasive fusariosis affects most patients with prolonged and profound neutropenia and/or severe T-cell immunodeficiency, acute leukemia, and hematopoietic cell transplant (HCT) recipients. Besides, it is not only the most frequent clinical form of fusariosis but also the most common challenging in immunocompromised patients, accounting for approximately $70 \%$ of all cases of fusariosis in this population [38]. A retrospective analysis of 233 cases $(92 \%$ of them being patients with hematologic diseases) reported that the outcome is usually poor, with a 90 -day probability of survival of $43 \%$ of the patients [77].

The typical clinical onset consists of a patient with prolonged ( $>10$ days) and profound $\left(<100 \mathrm{cells} / \mathrm{mm}^{3}\right)$ neutropenia who is persistently febrile and develops disseminated and characteristic skin lesions (papular or nodular erythematous lesions), with a positive blood culture [38,78]. Fusarium solani is the most common species involved in fusariosis (50\% of cases), followed by F. oxysporum (20\%), and F. verticillioidis and F. moniliforme (10\% each) [4].

In relation to pathogenesis, animal models of fusariosis showed that mortality was correlated with inoculum size [38]. In nonneutropenic mice, the disease was described by necrotizing abscesses with hyphae, hemorrhage, and neutrophil and macrophage infiltration [79]. Paradoxically, neutropenic mice did not exhibit an inflammatory cellular reaction and had a significantly higher fungal burden [79]. A murine model of intratracheal inoculation of $F$. solani was recently used to investigate its spread to different organs in immunocompetent animals within $24 \mathrm{~h}$ after inoculation. Results showed that a $1 \times 10^{8}$ conidia/animal inoculum followed a $100 \%$ death rate of immunocompetent mice in $24 \mathrm{~h}$ [80]. 


\section{Fusariosis Treatment}

Before reviewing any human fusariosis treatment, we must discuss a frequently forgotten issue in clinical practice: the role of the environment and fungicides in the patient response to antifungal drugs. Fungicides are chemical agents utilized for control and treatment of fungal infections in plants. They exhibit a variety of mechanisms of action, such as effects on respiration, signal transduction, mitosis cell division, membrane, and cell wall [81]. Also, azole fungicides, which include tebuconazole, propiconazole, and epoxiconazole, also called demethylation inhibitor (DMI), are the most widespread treatment in agriculture due to their low cost and broad spectrum [82]. For example, tebuconazole is generally used to control FHB (Fusarium head blight) [83]. Tebuconazole demonstrated various effects on Fusarium culmorum (a common pathogen of cereals), including morphological changes at the ultrastructural level such as considerable thickening of the hyphal cell walls, excessive septation, the formation of the incomplete septa, extensive vacuolization, accumulation of lipid bodies, and progressing necrosis or degeneration of the hyphal cytoplasm [84]. Morever, F. culmorum is capable of adapting to triazole pressure by overexpressing a drug resistance transporter [85].

As referenced before, the overuse of fungicides in crops and flower fields becomes imperative for the identification of Fusarium to the species level (some species have higher MIC values than others), not only from an epidemiological viewpoint but also for choosing the appropriate antifungal treatment [86].

\subsection{Localized Infection}

There are currently no available antifungal recommendations in accordance with Fusarium isolation. Treatment with nail lacquers and systemic treatment is usually used; unfortunately, Fusarium onychomycosis and keratitis are difficult to eradicate. Onychomycosis systemic treatment with itraconazole or terbinafine is usually effective, but relapses are very common [87]. Some Fusarium strains isolated from nail samples have also demonstrated in vitro susceptibility to amphotericin B (which binds to ergosterol in the cell membrane) [53]. Additionally, treating fungal keratitis represents a challenge because of the limited and variable susceptibility of Fusarium to antifungal agents, the poor tissue penetration of topical antifungal agents, resulting in low drug bioavailability, and the absence of routine determination of antifungal susceptibility [88]. First-line therapy for Fusarium keratitis includes a topical antifungal agent either alone or in combination with systemic antifungal medication. Natamycin (which inhibits fungal growth by binding to sterols) has been the traditional drug of choice for topical treatment; however, amphotericin B drops $(1.5 \mathrm{mg} / \mathrm{mL})$ and voriconazole have also been used [89]. A randomized trial comparing topical 5\% natamycin with topical voriconazole $1 \%$ for the treatment of fungal keratitis ( $24.6 \%$ of which were caused by Fusarium), suggested that natamycin may be more effective in healing corneal ulcers and improving visual acuity [90].

\subsection{Invasive Infection}

There is a variable susceptibility of Fusarium spp. to antifungal agents. The empirical treatment for invasive fusariosis infections is either voriconazole (VRC) (which inhibits the ergosterol production by binding and inhibiting the lanosterol-14alpha-demethylase), or liposomal amphotericin B (L-AMB), surgical debridement (if conceivable), and posaconazole (which inhibits the ergosterol production by binding and inhibiting the lanosterol-14alpha-demethylase) for salvage therapy [91]. If possible, neutropenia recovery and surgical debridement could be disease management tools. Information displays a 90-day survival rate of $42 \%$ in patients treated with voriconazole and showed that combined therapy does not work better than voriconazole alone [92]. In patients with acute leukemia, L-AMB or VCR are preferred. The ending point of invasive infection greatly depends on persistent neutropenia and or corticosteroid-induced immunosuppression [93]. In vitro synergism between antifungals and antimicrobials or non-antifungal agents have been studied, and percentages 
of synergism were as high as $80 \%$ for amiodarone (AMD) + VRC, of $75 \%$ for moxifloxacin and $A M B$, and of $65 \%$ for AMD + AMB [94].

\section{Antifungal Resistance Mechanisms}

In general, the members of Fusarium have shown primary or secondary resistance to practically all currently used antifungals, such as azoles, echinocandins, and polyenes [95]. An organism that is resistant to a drug prior to exposure is described as having primary or intrinsic resistance. Secondary resistance develops in response to exposure to an antimicrobial agent [96]. Both of these mechanisms have been reported in these fungi, although the molecular mechanisms of intrinsic resistance have not been described yet [11]. Secondary resistance to azoles has been demonstrated in A. fumigatus and is usually dependent on an altered expression of CYP51, the gene encoding sterol $14 \alpha$-demethylase [97,98]. In the Fusarium genus, there are three paralogous CYP51 genes which have been depicted and assigned as CYP51A, CYP51B, and CYP51C. In agriculture samples, the overexpression of CYP51A in F. graminearum in the presence of tebuconazole has already been described [99]. More recent evidence shows that $F$. keratoplasticum CYP51A mRNA levels are $\sim 6500$-fold upregulated in response to azole antifungals to compensate for the loss of CYP51B function due to azole inhibition. A strong association of voriconazole resistance with a $23 \mathrm{bp}$ CYP51A promoter deletion in F. keratoplasticum isolates was also demonstrated [100]. Lineage-specific (LS) chromosomes have been described in several plant pathogenic filamentous fungi. A recent study discovered the presence of LS in two F. oxysporum clinical strains with an important role in niche adaptation and resistance, for example, a doubling of genes coding for ergosterol synthesis and, in addition, more than 70 copies of genes coding for various efflux pumps [101].

Furthermore, it was reported recently that several genes of F. oxysporum and F. solani related to mechanisms of antifungal resistance such as ergosterol synthesis pathways, drug efflux pumps, response to oxidative stress, and cell wall biosynthesis, were differentially regulated upon the treatment with amphotericin B (AMB) and posaconazole (PSC) [102].

\section{One Health Perspective}

The emphasis of the One Health approach may explain common intersecting points, such as STEF disease, and plumbing human contaminations, hospital water, and air distribution systems are reservoirs for the fungi. Other risks of human infection come from environmental sources, for example, keratitis may develop following the traumatic inoculation with Fusarium-contaminated soil or plant material (Figure 1).

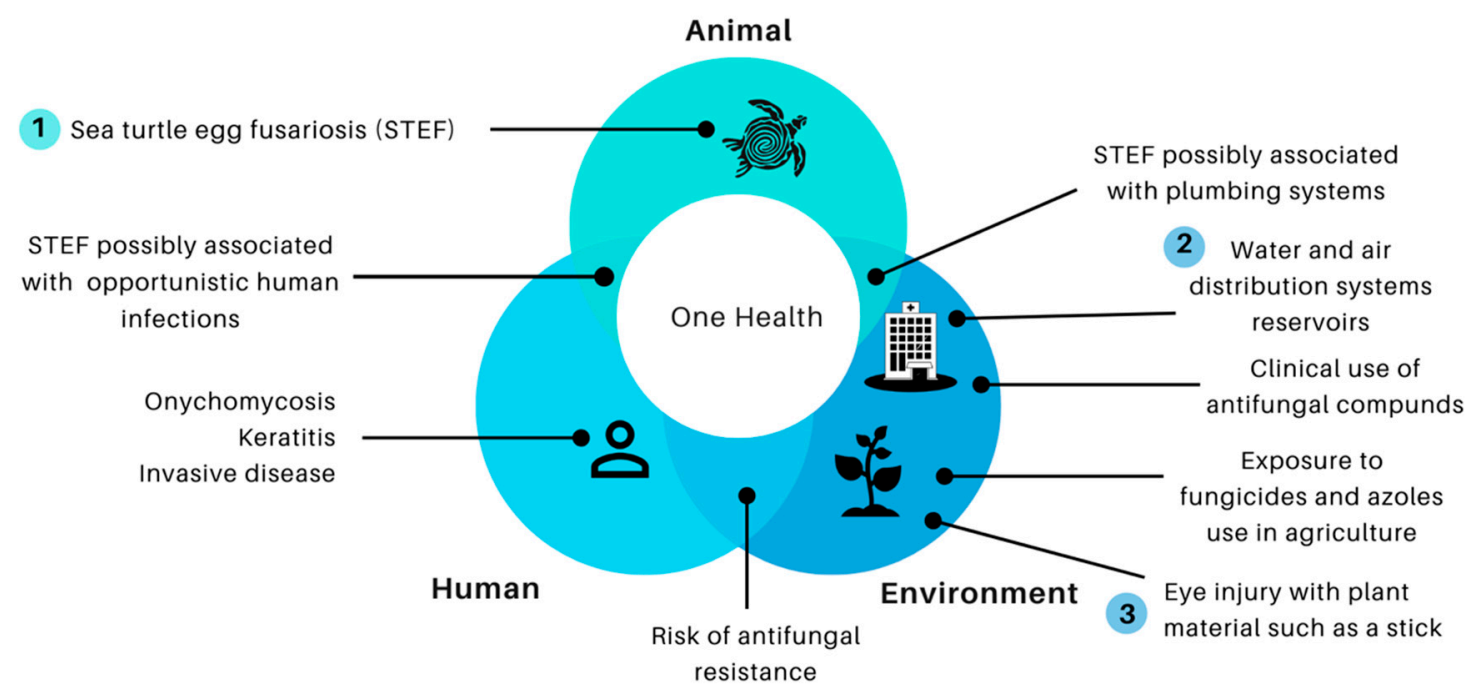

Figure 1. Animal, environment, and human interaction: a One Health perspective. 
Furthermore, the extensive use of azoles fungicides in agriculture leading to a risk of antifungal resistance in humans is a significant issue of concern. Azole fungicides utilized in agriculture share the same mechanism of action (inhibition of lanosterol-14 $\alpha$-demethylase) and similar molecular structures (pharmcophores) as medical triazole drugs [103]. Furthermore, a recent rate of emergence of fungicide-resistance pathogens has been reported [104]. Overall, all these findings challenge clinicians and researchers to understand every part of the puzzle. We must continue efforts to think outside the box, and work together with all actors of One Health initiatives. One Health must integrate fungal diseases into health systems [105] and improve interdisciplinarity studies that include the patient, the environment, and the relationship among all the elements that affect fusariosis in agriculture, and human and animal diseases.

\section{Conclusions}

Data from fusariosis in animals and plants are vital to understanding human infections. Fungicide controls fungal diseases but many fungicides share target activity with antifungals. This explains why the high use of fungicides in agriculture is risky for developing resistance to antifungals in clinical practice. To recognize fusariosis disease correctly in humans, animals, and plants, epidemiological information and research should be done across all segments. Government, agriculture, clinical, veterinarian, and plant authorities must initiate joint actions in order to respond to the One Health approach in fusariosis.

Author Contributions: Conceptualization, V.S. and A.M.C.R.; writing-original draft preparation, V.S., C.A.-M., P.L.P., S.R., J.G., and A.M.C.R. All authors have read and agreed to the published version of the manuscript.

Funding: This research received no external funding.

Acknowledgments: All authors acknowledge financial support provided by the Vice Presidency for Research \& Creation publication fund at the Universidad de los Andes.

Conflicts of Interest: The authors declare no conflict of interest.

\section{References}

1. One Health Initiative One Health Initiative Will Unite Human and Veterinary Medicine. Available online: http://www.onehealthinitiative.com (accessed on 18 February 2020).

2. Gauthier, G.M.; Keller, N.P. Crossover fungal pathogens: The biology and pathogenesis of fungi capable of crossing kingdoms to infect plants and humans. Fungal Genet. Biol. 2013, 61, 146-157. [CrossRef] [PubMed]

3. Jain, P.K.; Gupta, V.K.; Misra, A.K.; Gaur, R.; Bajpai, V.; Issar, S. Current status of Fusarium infection in human and animal. Asian J. Anim. Vet. Adv. 2011, 6, 201-227. [CrossRef]

4. Moretti, M.L.; Busso-Lopes, A.F.; Tararam, C.A.; Moraes, R.; Muraosa, Y.; Mikami, Y.; Gonoi, T.; Taguchi, H.; Lyra, L.; Reichert-Lima, F.; et al. Airborne transmission of invasive fusariosis in patients with hematologic malignancies. PLoS ONE 2018, 13, e0196426. [CrossRef] [PubMed]

5. Garnica, M.; Nucci, M. Epidemiology of fusariosis. Curr. Fungal Infect. Rep. 2013, 7, 301-305. [CrossRef]

6. Whitcher, J.P.; Srinivasan, M.; Upadhyay, M.P. Corneal blindness: A global perspective. Bull. World Health Organ. 2001, 79, 214-221.

7. Chidambaram, J.D.; Venkatesh Prajna, N.; Srikanthi, P.; Lanjewar, S.; Shah, M.; Elakkiya, S.; Lalitha, P.; Burton, M.J. Epidemiology, risk factors, and clinical outcomes in severe microbial keratitis in South India. Ophthalmic Epidemiol. 2018, 25, 297-305. [CrossRef]

8. Nelson, P.E.; Dignani, M.C.; Anaissie, E.J. Taxonomy, biology, and clinical aspects of Fusarium species. Clin. Microbiol. Rev. 1994, 7, 479-504. [CrossRef]

9. Guarro, J. Fusariosis, a complex infection caused by a high diversity of fungal species refractory to treatment. Eur. J. Clin. Microbiol. Infect. Dis. 2013, 32, 1491-1500. [CrossRef]

10. Van Diepeningen, A.D.; Al-Hatmi, A.M.S.; Brankovics, B.; de Hoog, G.S. Taxonomy and Clinical Spectra of Fusarium Species: Where Do We Stand in 2014? Curr. Clin. Microbiol. Rep. 2014, 1, 10-18. [CrossRef]

11. Al-Hatmi, A.M.S.; Sybren de Hoog, G.; Meis, J.F. Multiresistant fusarium pathogens on plants and humans: Solutions in (from) the antifungal pipeline? Infect. Drug Resist. 2019, 12, 3727-3737. [CrossRef] 
12. Lombard, L.; van der Merwe, N.A.; Groenewald, J.Z.; Crous, P.W. Generic concepts in Nectriaceae. Stud. Mycol. 2015, 80, 189-245. [CrossRef]

13. Wiederhold, N.; Gibas, C. From the Clinical Mycology Laboratory: New Species and Changes in Fungal Taxonomy and Nomenclature. J. Fungi 2018, 4, 138. [CrossRef] [PubMed]

14. Sandoval-Denis, M.; Crous, P.W. Removing chaos from confusion: Assigning names to common human and animal pathogens in Neocosmospora. Pers. Mol. Phylogeny Evol. Fungi 2018, 41, 109-129. [CrossRef] [PubMed]

15. Geiser, D.M.; Adam, G.; Alastruey-Izquierdo, A.; Alberts, J.F.; Al-Hatmi, A.M.S.; Aoki, T.; Baker, S.E.; Balmas, V.; Battacharyya, M.K.; Blomquist, C.L.; et al. A monophyletic Fusarium that includes Fusarium solani species complex is strongly supported by a 19-gene phylogenomic analysis. Phytopathology 2020. Paper under review.

16. O’Donnell, K.; Al-Hatmi, A.M.; Aoki, T.; Brankovics, B.; Cano-Lira, J.F.; Coleman, J.J.; Sybren de Hoog, G.; Di Pietro, A.; Frandsen, R.J.N.; Geiser, D.M.; et al. No to Neocosmpospora: Phylogenomic and practical reasons for continued inclusions of the Fusarium solani complex in the genus Fusarium. mSphere 2020, 5, e00810-20. [CrossRef] [PubMed]

17. van Diepeningen, A.D.; de Hoog, G.S. Challenges in Fusarium, a Trans-Kingdom Pathogen. Mycopathologia 2016, 181, 161-163. [CrossRef] [PubMed]

18. Elvers, K.T.; Leeming, K.; Moore, C.P.; Lappin-Scott, H.M. Bacterial-fungal biofilms in flowing water photo-processing tanks. J. Appl. Microbiol. 1998, 84, 607-618. [CrossRef] [PubMed]

19. Zhang, N.; O’Donnell, K.; Sutton, D.A.; Nalim, F.A.; Summerbell, R.C.; Padhye, A.A.; Geiser, D.M. Members of the Fusarium solani species complex that cause infections in both humans and plants are common in the environment. J. Clin. Microbiol. 2006, 44, 2185-2190. [CrossRef]

20. Dean, R.; Van Kan, J.A.L.; Pretorius, Z.A.; Hammond-Kosack, K.E.; Di Pietro, A.; Spanu, P.D.; Rudd, J.J.; Dickman, M.; Kahmann, R.; Ellis, J.; et al. The Top 10 fungal pathogens in molecular plant pathology. Mol. Plant Pathol. 2012, 13, 414-430. [CrossRef]

21. Gullino, M.L.; Daughtrey, M.L.; Garibaldi, A.; Elmer, W.H. Fusarium wilts of ornamental crops and their management. Crop Prot. 2015, 73, 50-59. [CrossRef]

22. Wu, F. Measuring the economic impacts of Fusarium toxins in animal feeds. Anim. Feed Sci. Technol. 2007, 137, 363-374. [CrossRef]

23. Singh, R.P.; Singh, P.K.; Rutkoski, J.; Hodson, D.P.; He, X.; Jørgensen, L.N.; Hovmøller, M.S.; Huerta-Espino, J. Disease Impact on Wheat Yield Potential and Prospects of Genetic Control. Annu. Rev. Phytopathol. 2016, 54, 303-322. [CrossRef] [PubMed]

24. Azevedo, M.M.; Faria-Ramos, I.; Cruz, L.C.; Pina-Vaz, C.; Gonçalves Rodrigues, A. Genesis of Azole Antifungal Resistance from Agriculture to Clinical Settings. J. Agric. Food Chem. 2015, 63, 7463-7468. [CrossRef] [PubMed]

25. Alvarez-Moreno, C.; Lavergne, R.A.; Hagen, F.; Morio, F.; Meis, J.F.; Le Pape, P. Azole-resistant Aspergillus fumigatus harboring TR 34 /L98H, TR 46/Y121F/T289A and TR 53 mutations related to flower fields in Colombia. Sci. Rep. 2017, 7, 1-8. [CrossRef]

26. Schoustra, S.E.; Debets, A.J.M.; Rijs, A.J.M.M.; Zhang, J.; Snelders, E.; Leendertse, P.C.; Melchers, W.J.G.; Rietveld, A.G.; Zwaan, B.J.; Verweij, P.E. Environmental hotspots for azole resistance selection of Aspergillus fumigatus, The Netherlands. Emerg. Infect. Dis. 2019, 25, 1347-1353. [CrossRef]

27. Godeau, C.; Reboux, G.; Scherer, E.; Laboissiere, A.; Lechenault-Bergerot, C.; Millon, L.; Rocchi, S. Azole-resistant Aspergillus fumigatus in the hospital: Surveillance from flower beds to corridors. Am. J. Infect. Control 2019, 48, 2019-2021. [CrossRef]

28. Dunne, K.; Hagen, F.; Pomeroy, N.; Meis, J.F.; Rogers, T.R. Intercountry Transfer of Triazole-Resistant Aspergillus fumigatus on Plant Bulbs. Clin. Infect. Dis. 2017, 65, 147-149. [CrossRef]

29. Buil, J.B.; Hare, R.K.; Zwaan, B.J.; Arendrup, M.C.; Melchers, W.J.G.; Verweij, P.E. The fading boundaries between patient and environmental routes of triazole resistance selection in Aspergillus fumigatus. PLoS Pathog. 2019, 15, 1-8. [CrossRef]

30. Riat, A.; Plojoux, J.; Gindro, K.; Schrenzel, J.; Sanglard, D. Azole Resistance of Environmental and Clinical Aspergillus. Antimicrob. Agents Chemother. 2018, 4, 1-7. 
31. Homa, M.; Galgóczy, L.; Manikandan, P.; Narendran, V.; Sinka, R.; Csernetics, á.; Vágvölgyi, C.; Kredics, L.; Papp, T. South Indian Isolates of the Fusarium solani species complex from clinical and environmental samples: Identification, antifungal susceptibilities, and virulence. Front. Microbiol. 2018, 9, 1-14. [CrossRef]

32. Colombia.Co En Floricultura, La Respuesta Es Colombia. Available online: https://www.colombia.co/paiscolombia/hechos/en-floricultura-la-respuesta-es-colombia-2/ (accessed on 2 March 2020).

33. Alvarez-Moreno, C.; Lavergne, R.A.; Hagen, F.; Morio, F.; Meis, J.F.; Le Pape, P. Fungicide-driven alterations in azole-resistant Aspergillus fumigatus are related to vegetable crops in Colombia, South America. Mycologia 2019, 111, 217-224. [CrossRef] [PubMed]

34. Anaissie, E.J.; Kuchar, R.T.; Rex, J.H.; Francesconi, A.; Kasai, M.; Müller, F.C.; Lozano-Chiu, M.; Summerbell, R.C.; Dignani, M.C.; Chanock, S.J.; et al. Fusariosis Associated with Pathogenic Fusarium Species Colonization of a Hospital Water System: A New Paradigm for the Epidemiology of Opportunistic Mold Infections. Clin. Infect. Dis. 2002, 33, 1871-1878. [CrossRef] [PubMed]

35. Short, D.P.G.; O'Donnell, K.; Zhang, N.; Juba, J.H.; Geiser, D.M. Widespread occurrence of diverse human pathogenic types of the fungus Fusarium detected in plumbing drains. J. Clin. Microbiol. 2011, 49, 4264-4272. [CrossRef] [PubMed]

36. Litvinov, N.; da Silva, M.T.N.; van der Heijden, I.M.; Graça, M.G.; Marques de Oliveira, L.; Fu, L.; Giudice, M.; Zilda de Aquino, M.; Odone-Filho, V.; Marques, H.H.; et al. An outbreak of invasive fusariosis in a children's cancer hospital. Clin. Microbiol. Infect. 2015, 21, 268.e1-268.e7. [CrossRef]

37. Carter, C.D.; Barr, B.A. Infection control issues in construction and renovation. Infect. Control. Hosp. Epidemiol. 1997, 18, 587-596. [CrossRef]

38. Nucci, M.; Anaissie, E. Fusarium infections in immunocompromised patients. Clin. Microbiol. Rev. 2007, 20, 695-704. [CrossRef]

39. Cafarchia, C.; Paradies, R.; Figueredo, L.A.; Iatta, R.; Desantis, S.; Di Bello, A.V.F.; Zizzo, N.; van Diepeningen, A.D. Fusarium spp. in Loggerhead Sea Turtles (Caretta caretta): From Colonization to Infection. Vet. Pathol. 2020, 57, 139-146. [CrossRef]

40. Garcia-Hartmann, M.; Hennequin, C.; Catteau, S.; Béatini, C.; Blanc, V. Cas groupés d'infection à Fusarium solani chez de jeunes tortues marines Caretta caretta nées en captivité. J. Mycol. Med. 2017, 27, 113-118. [CrossRef]

41. Smyth, C.W.; Sarmiento-Ramírez, J.M.; Short, D.P.G.; Diéguez-Uribeondoid, J.; O'donnell, K.; Geiser, D.M. Unraveling the ecology and epidemiology of an emerging fungal disease, sea turtle egg fusariosis (STEF). PLoS Pathog. 2019, 15, 1-6. [CrossRef] [PubMed]

42. Bhupathy, S.; Saravanan, S. Status of Marine Turtles in the Gulf of Mannar, India. Chelonian Conserv. Biol. 2006, 5, 139. [CrossRef]

43. Gleason, F.H.; Allerstorfer, M.; Lilje, O. Newly emerging diseases of marine turtles, especially sea turtle egg fusariosis (SEFT), caused by species in the Fusarium solani complex (FSSC). Mycology 2020, 11, 184-194. [CrossRef]

44. Sarmiento-Ramirez, J.M.; Sim, J.; Van West, P.; Dieguez-Uribeondo, J. Isolation of fungal pathogens from eggs of the endangered sea turtle species Chelonia mydas in Ascension Island. J. Mar. Biol. Assoc. UK 2017, 97, 661-667. [CrossRef]

45. Sarmiento-Ramírez, J.M.; Abella, E.; Martín, M.P.; Tellería, M.T.; López-Jurado, L.F.; Marco, A.; Diéguez-Uribeondo, J. Fusarium solani is responsible for mass mortalities in nests of loggerhead sea turtle, Caretta caretta, in Boavista, Cape Verde. FEMS Microbiol. Lett. 2010, 312, 192-200. [CrossRef] [PubMed]

46. Mallik, S.K.; Shahi, N.; Joshi, N.; Pant, K.; Kala, K.; Chandra, S.; Sarma, D. The emergence of zoonotic Fusarium oxysporum infection in captive-reared fingerlings of golden mahseer, Tor putitora (Hamilton, 1822) from the central Himalayan region of India. Transbound. Emerg. Dis. 2020, 67, 555-563. [CrossRef]

47. O’Donnell, K.; Sutton, D.A.; Wiederhold, N.; Robert, V.A.R.G.; Crous, P.W.; Geiser, D.M. Veterinary fusarioses within the United States. J. Clin. Microbiol. 2016, 54, 2813-2819. [CrossRef]

48. O'Donnell, K.; Sutton, D.A.; Rinaldi, M.G.; Sarver, B.A.J.; Balajee, S.A.; Schroers, H.J.; Summerbell, R.C.; Robert, V.A.R.G.; Crous, P.W.; Zhang, N.; et al. Internet-accessible DNA sequence database for identifying fusaria from human and animal infections. J. Clin. Microbiol. 2010, 48, 3708-3718. [CrossRef]

49. Adhikari, M.; Negi, B.; Kaushik, N.; Adhikari, A.; Al-Khedhairy, A.A.; Kaushik, N.K.; Choi, E.H. T-2 mycotoxin: Toxicological effects and decontamination strategies. Oncotarget 2017, 8, 33933-33952. [CrossRef] 
50. Lipner, S.R.; Scher, R.K. Onychomycosis: Clinical overview and diagnosis. J. Am. Acad. Derm. 2019, 80, 835-851. [CrossRef]

51. Thomas, J.; Jacobson, G.A.; Narkowicz, C.K.; Peterson, G.M.; Burnet, H.; Sharpe, C. Toenail onychomycosis: An important global disease burden. J. Clin. Pharm. 2010, 35, 497-519.

52. Eewski, B.E. Onychomycosis: Treatment, quality of life, and economic issues. Am. J. Clin. Derm. 2000, 1, 19-26. [CrossRef]

53. Guevara-Suarez, M.; Cano-Lira, J.F.; Cepero de García, M.C.; Sopo, L.; De Bedout, C.; Cano, L.E.; García, A.M.; Motta, A.; Amézquita, A.; Cárdenas, M.; et al. Genotyping of Fusarium Isolates from Onychomycoses in Colombia: Detection of Two New Species Within the Fusarium solani Species Complex and In Vitro Antifungal Susceptibility Testing. Mycopathologia 2016, 181, 165-174. [CrossRef]

54. Gupta, A.K.; Drummond-Main, C.; Cooper, E.A.; Brintnell, W.; Piraccini, B.M.; Tosti, A. Systematic review of nondermatophyte mold onychomycosis: Diagnosis, clinical types, epidemiology, and treatment. J. Am. Acad. Derm. 2012, 66, 494-502. [CrossRef] [PubMed]

55. Monod, M.; Méhul, B. Recent findings in onychomycosis and their application for appropriate treatment. J. Fungi 2019, 5, 20. [CrossRef] [PubMed]

56. Veiga, F.F.; De Castro-Hoshino, L.V.; Sato, F.; Bombassaro, A.; Vicente, V.A.; Mendes, V.; Baesso, M.L.; Negri, M.; Svidzinski, T.I.E. Fusarium oxysporum is an onychomycosis etiopathogenic agent. Future Microbiol. 2018, 13, 1745-1756. [CrossRef] [PubMed]

57. Majumdar, S.; Pal, S. Information transmission in microbial and fungal communication: From classical to quantum. J. Cell Commun. Signal. 2018, 12, 491-502. [CrossRef]

58. Gupta, A.K.; Daigle, D.; Carviel, J.L. The role of biofilms in onychomycosis. J. Am. Acad. Derm. 2016, 74, 1241-1246. [CrossRef] [PubMed]

59. Ung, L.; Bispo, P.J.M.; Shanbhag, S.S.; Gilmore, M.S.; Chodosh, J. The persistent dilemma of microbial keratitis: Global burden, diagnosis, and antimicrobial resistance. Surv. Ophthalmol. 2019, 64, 255-271. [CrossRef]

60. Wong, T.Y.; Ng, T.P.; Fong, K.S.; Tan, D.T.H. Risk factors and clinical outcomes between fungal and bacterial keratitis: A comparative study. CLAO J. 1997, 23, 275-281.

61. Sun, S.; Lui, Q.; Han, L.; Ma, Q.; He, S.; Li, X.; Zhang, H.; Zhang, J.; Liu, X.; Wang, L. Identification and Characterization of Fusarium proliferatum, a New Species of Fungi that Cause Fungal Keratitis. Sci. Rep. 2018, 8, 1-9. [CrossRef]

62. Tuli, S. Fungal keratitis. Clin. Ophthalmol. 2011, 5, 275-279. [CrossRef]

63. Shah, A.; Sachdev, A.; Coggon, D.; Hossain, P. Geographic variations in microbial keratitis: An analysis of the peer-reviewed literature. Br. J. Ophthalmol. 2011, 95, 762-767. [CrossRef] [PubMed]

64. Ma, S.K.E.; So, K.; Chung, P.H.; Tsang, H.F.; Chuang, S.K. A multi-country outbreak of fungal keratitis associated with a brand of contact lens solution: The Hong Kong experience. Int. J. Infect. Dis. 2009, 13, 443-448. [CrossRef] [PubMed]

65. Lakhundi, S.; Siddiqui, R.; Khan, N.A. Pathogenesis of microbial keratitis. Microb. Pathog. 2017, 104, 97-109. [CrossRef] [PubMed]

66. Thomas, P.A.; Kaliamurthy, J. Mycotic keratitis: Epidemiology, diagnosis and management. Clin. Microbiol. Infect. 2013, 19, 210-220. [CrossRef]

67. Oechsler, R.A.; Feilmeier, M.R.; Miller, D.; Shi, W.; Hofling-Lima, A.L.; Alfonso, E.C. Fusarium keratitis: Genotyping, in vitro susceptibility and clinical outcomes. Cornea 2013, 32, 667-673. [CrossRef] [PubMed]

68. Cheikhrouhou, F.; Makni, F.; Neji, S.; Trigui, A.; Sellami, H.; Trabelsi, H.; Guidara, R.; Fki, J.; Ayadi, A. Epidemiological profile of fungal keratitis in Sfax (Tunisia). J. Mycol. Med. 2014, 24, 308-312. [CrossRef]

69. Muller, G.; Kara-Jose, N.; Silvestre, R. Perfil epidemiológico das ceratomicoses atendidas no HC-UNICAMP. Arq. Bras. Oftalmol. 2012, 75, 247-250. [CrossRef]

70. Vanzzini Zago, V.; Manzano-Gayosso, P.; Hernández-Hernández, F.; Méndez-Tovar, L.J.; Gómez-Leal, A.; López Martínez, R. Queratomicosis en un centro de atención oftalmológica en la Ciudad de México. Rev. Iberoam. Micol. 2010, 27, 57-61. [CrossRef]

71. Yang, W.; Zhang, L. Association of Tear Film Stability and Corneal Surface Temperature in Pudong Patients. Curr. Eye Res. 2017, 42, 655-660. [CrossRef]

72. Jones, B.R. Principles in the management of oculomycosis. XXXI Edward Jackson Memorial Lecture. Am. J. Ophthalmol. 1975, 79, 719-751. [CrossRef] 
73. Raza, S.K.; Mallet, A.I.; Howell, S.A.; Thomas, P.A. An in-vitro study of the sterol content and toxin production of Fusarium isolates from mycotic keratitis. J. Med. Microbiol. 1994, 41, 204-208. [CrossRef] [PubMed]

74. Niu, L.; Liu, X.; Ma, Z.; Yin, Y.; Sun, L.; Yang, L.; Zheng, Y. Fungal keratitis: Pathogenesis, diagnosis and prevention. Microb. Pathog. 2020, 138,1-10. [CrossRef]

75. Córdova-Alcántara, I.M.; Venegas-Cortés, D.L.; Martínez-Rivera, M.Á.; Pérez, N.O.; Rodriguez-Tovar, A.V. Biofilm characterization of Fusarium solani keratitis isolate: Increased resistance to antifungals and UV light. J. Microbiol. 2019, 57, 485-497. [CrossRef] [PubMed]

76. Calvillo-Medina, R.P.; Reyes-Grajeda, J.P.; Barba-Escoto, L.; Bautista-Hernandez, L.A.; Campos-Guillén, J.; Jones, G.H.; Bautista-de Lucio, V.M. Proteome analysis of biofilm produced by a Fusarium falciforme keratitis infectious agent. Microb. Pathog. 2019, 130, 232-241. [CrossRef]

77. Nucci, M.; Marr, K.A.; Vehreschild, M.J.G.T.; de Souza, C.A.; Velasco, E.; Cappellano, P.; Carlesse, F.; Queiroz-Telles, F.; Sheppard, D.C.; Kindo, A.; et al. Improvement in the outcome of invasive fusariosis in the last decade. Clin. Microbiol. Infect. 2014, 20, 580-585. [CrossRef]

78. Nucci, M.; Anaissie, E. Cutaneous Infection by Fusarium Species in Healthy and Immunocompromised Hosts: Implications for Diagnosis and Management. Clin. Infect. Dis. 2002, 35, 909-920. [CrossRef]

79. Legrand, C.; Anaissie, E.; Hashem, R.; Nelson, P.; Bodey, G.P.; Ro, J. Experimental fusarial hyalohyphomycosis in a murine model. J. Infect. Dis. 1991, 164, 944-948. [CrossRef]

80. Costa, M.I.; Vilugron Rodrigues, F.A.; Veiga, F.F.; Jarros, I.C.; Kischkel, B.; Negri, M.; Alexandrino Becker, T.C.; Svidzinski, T.I.E. Effects of intratracheal Fusarium solani inoculation in immunocompetent mice. Microb. Pathog. 2019, 128, 317-322. [CrossRef]

81. Yang, C.; Hamel, C.; Vujanovic, V.; Gan, Y. Fungicide: Modes of Action and Possible Impact on Nontarget Microorganisms. ISRN Ecol. 2011, 2011, 1-8. [CrossRef]

82. Price, C.L.; Parker, J.E.; Warrilow, A.G.; Kelly, D.E.; Kelly, S.L. Azole fungicides—understanding resistance mechanisms in agricultural fungal pathogens. Pest Manag. Sci. 2015, 71, 1054-1058. [CrossRef]

83. Qian, H.; Du, J.; Chi, M.; Sun, X.; Liang, W.; Huang, J.; Li, B. The Y137H mutation in the cytochrome P450 FgCYP51B protein confers reduced sensitivity to tebuconazole in Fusarium graminearum. Pest Manag. Sci. 2018, 74, 1472-1477. [CrossRef]

84. Kang, Z.; Huang, L.; Krieg, U.; Mauler-Machnik, A.; Buchenauer, H. Effects of tebuconazole on morphology, structure, cell wall components and trichothecene production of Fusarium culmorum in vitro. Pest Manag. Sci. 2001, 57, 491-500. [CrossRef] [PubMed]

85. Hellin, P.; King, R.; Urban, M.; Hammond-Kosack, K.E.; Legrève, A. The adaptation of Fusarium culmorum to DMI fungicides is mediated by major transcriptome modifications in response to azole fungicide, including the overexpression of a PDR transporter (FcABC1). Front. Microbiol. 2018, 9, 1-15. [CrossRef] [PubMed]

86. Al-Hatmi, A.; Curfs-Breuker, I.; de Hoog, G.; Meis, J.; Verweij, P. Antifungal Susceptibility Testing of Fusarium: A Practical Approach. J. Fungi 2017, 3, 19. [CrossRef]

87. Tosti, A.; Piraccini, B.M.; Lorenzi, S.; Iorizzo, M. Treatment of nondermatophyte mold and Candida onychomycosis. Derm. Clin. 2003, 21, 491-497. [CrossRef]

88. Sahay, P.; Singhal, D.; Nagpal, R.; Maharana, P.K.; Farid, M.; Gelman, R.; Sinha, R.; Agarwal, T.; Titiyal, J.S.; Sharma, N. Pharmacologic therapy of mycotic keratitis. Surv. Ophthalmol. 2019, 64, 380-400. [CrossRef]

89. Bunya, V.Y.; Hammersmith, K.M.; Rapuano, C.J.; Ayres, B.D.; Cohen, E.J. Topical and Oral Voriconazole in the Treatment of Fungal Keratitis. Am. J. Ophthalmol. 2007, 143, 151-153. [CrossRef] [PubMed]

90. Sharma, S.; Das, S.; Virdi, A.; Fernandes, M.; Sahu, S.K.; Koday, N.K.; Ali, M.H.; Garg, P.; Motukupally, S.R. Re-appraisal of topical $1 \%$ voriconazole and $5 \%$ natamycin in the treatment of fungal keratitis in a randomised trial. Br. J. Ophthalmol. 2015, 99, 1190-1195. [CrossRef] [PubMed]

91. Lainhart, W. Fusarium spp., a Genus of Common PlantPathogens That Can Cause Devastating, Opportunistic Human Disease. Clin. Microbiol. Newsl. 2018, 40, 1-5. [CrossRef]

92. Lortholary, O.; Obenga, G.; Biswas, P.; Caillot, D.; Chachaty, E.; Bienvenu, A.L.; Cornet, M.; Greene, J.; Herbrecht, R.; Lacroix, C.; et al. International retrospective analysis of 73 cases of invasive fusariosis treated with voriconazole. Antimicrob. Agents Chemother. 2010, 54, 4446-4450. [CrossRef]

93. Nucci, M.; Anaissie, E. How we treat invasive fungal diseases in patients with acute leukemia: The importance of an individualized approach. Blood 2014, 124, 3858-3870. [CrossRef] 
94. Venturini, T.P.; Al-Hatmi, A.M.S.; Rossato, L.; Azevedo, M.I.; Keller, J.T.; Weiblen, C.; Santurio, J.M.; Alves, S.H. Do antibacterial and antifungal combinations have better activity against clinically relevant fusarium species? In vitro synergism. Int. J. Antimicrob. Agents 2018, 51, 784-788. [CrossRef]

95. Al-Hatmi, A.M.S.; Meis, J.F.; de Hoog, G.S. Fusarium: Molecular Diversity and Intrinsic Drug Resistance. PLoS Pathog. 2016, 12, e1005464. [CrossRef]

96. White, T.C.; Marr, K.A.; Bowden, R.A. Clinical, cellular, and molecular factors that contribute to antifungal drug resistance. Clin. Microbiol. Rev. 1998, 11, 382-402. [CrossRef] [PubMed]

97. Parker, J.E.; Warrilow, A.G.S.; Price, C.L.; Mullins, J.G.L.; Kelly, D.E.; Kelly, S.L. Resistance to antifungals that target CYP51. J. Chem. Biol. 2014, 7, 143-161. [CrossRef]

98. Pérez-Cantero, A.; López-Fernández, L.; Guarro, J.; Capilla, J. Azole resistance mechanisms in Aspergillus: Update and recent advances. Int. J. Antimicrob. Agents 2020, 55, 1-10. [CrossRef]

99. Becher, R.; Weihmann, F.; Deising, H.B.; Wirsel, S.G.R. Development of a novel multiplex DNA microarray for Fusarium graminearum and analysis of azole fungicide responses. BMC Genom. 2011, 12, 1-17. [CrossRef] [PubMed]

100. James, J.E.; Lamping, E.; Santhanam, J.; Milne, T.J.; Abd Razak, M.F.; Zakaria, L.; Cannon, R.D. A 23 bp cyp51A Promoter Deletion Associated With Voriconazole Resistance in Clinical and Environmental Isolates of Neocosmospora keratoplastica. Front. Microbiol. 2020, 11, 1-15. [CrossRef]

101. Zhang, Y.; Yang, H.; Turra, D.; Zhou, S.; Ayhan, D.H.; Delulio, G.A.; Guo, L.; Broz, K.; Wiederhold, N.; Coleman, J.J.; et al. The genome of opportunistic fungal pathogen Fusarium oxysporum carries a unique set of lineage-specific chromosomes. Commun. Biol. 2020, 3, 1-12. [CrossRef]

102. Castillo-Castañeda, A.; Cañas-Duarte, S.J.; Guevara-Suarez, M.; Guarro, J.; Restrepo, S.; Celis Ramírez, A.M. Transcriptional response of Fusarium oxysporum and Neocosmospora solani challenged with amphotericin B or posaconazole. Microbiology 2020, 166, 1-11. [CrossRef] [PubMed]

103. Chowdhary, A.; Kathuria, S.; Xu, J.; Meis, J.F. Emergence of Azole-Resistant Aspergillus fumigatus Strains due to Agricultural Azole Use Creates an Increasing Threat to Human Health. PLoS Pathog. 2013, 9, 3-7. [CrossRef]

104. Brauer, V.S.; Rezende, C.P.; Pessoni, A.M.; De Paula, R.G.; Rangappa, K.S.; Nayaka, S.C.; Gupta, V.K.; Almeida, F. Antifungal agents in agriculture: Friends and foes of public health. Biomolecules 2019, 9, 521. [CrossRef] [PubMed]

105. Rodriguez Tudela, J.L.; Cole, D.C.; Ravasi, G.; Bruisma, N.; Chiller, T.C.; Ford, N.; Denning, D.W. Integration of fungal diseases into health systems in Latin America. Lancet Infect. Dis. 2020, 20, 890-892. [CrossRef]

Publisher's Note: MDPI stays neutral with regard to jurisdictional claims in published maps and institutional affiliations.

(C) 2020 by the authors. Licensee MDPI, Basel, Switzerland. This article is an open access article distributed under the terms and conditions of the Creative Commons Attribution (CC BY) license (http://creativecommons.org/licenses/by/4.0/). 